\title{
Modeling the effectiveness of electronic customer relationship management (E-CRM) systems: empirical evidence from Pakistan
}

\section{Maryam Tariq}

Department of business administration, National College of Business Administration \& Economics, Rahim Yar Khan, Pakistan

\section{Ahmed Jamil}

Department of business administration, National College of Business Administration \& Economics, Rahim Yar Khan, Pakistan

Muhammad Shakil Ahmad

Department of Management Science, COMSATS University Islamabad, Attock Campus, Attock, Kamra Road, 43600, Attock

\section{T. Ramayah}

School of Management, Universiti Sains Malaysia, 11800, Minden, Penang, Malaysia

Corresponding Author Email: onlyshakil@gmail.com

\section{Editor Científico: José Edson Lara}

Organização Comitê Científico

Double Blind Review pelo SEER/OJS

Recebido em 10.07.2019

Aprovado em 13.08.2019 


\begin{abstract}
The purpose of this study is to find the relationship of service quality, loyalty, trust employee satisfaction and technology acceptance with the effectiveness of electronic customer relationship management. Organizations are introducing internet based technology to make their business convenient for the existing as well as potential customers and through their feedback also manage their performance. The research was conducted in the banking sector of Pakistan and data was collected from over 500 employees and customers including the top five banks of the country. The findings showed that only service quality and loyalty were the significant predictors of E_CRM system effectiveness. It is anticipated that results of this study will not only expand the scope of study for researchers at the academic level, but also may make policy makers and managers to realize the significance of E-CRM. Its implementation will ultimately result in achieving the higher level of customer satisfaction which is imperative in banking sector.
\end{abstract}

Keywords: E-CRM; Customer Loyalty; Employee Satisfaction; Service Quality; Trust; Technology Acceptance

\title{
Modelando a efetividade dos sistemas de gerenciamento eletrônico de relacionamento com clientes (E-CRM): evidências empíricas do Paquistão
}

\section{Resumo}

O objetivo deste estudo é encontrar a relação de qualidade de serviço, lealdade, confiança na satisfação do empregado e aceitação da tecnologia com a eficácia da gestão eletrônica do relacionamento com o cliente. As organizações estão introduzindo a tecnologia baseada na Internet para tornar seus negócios mais convenientes para os clientes existentes e potenciais e, por meio de seus comentários, também gerenciam seu desempenho. A pesquisa foi realizada no setor bancário do Paquistão e os dados foram coletados de mais de 500 funcionários e clientes, incluindo os cinco principais bancos do país. Os resultados mostraram que apenas a qualidade e a lealdade do serviço foram os preditores significativos da eficácia do sistema e-CRM. Prevêse que os resultados deste estudo não só ampliem o escopo do estudo para pesquisadores no nível acadêmico, mas também possam fazer com que formuladores de políticas e gerentes percebam o significado do e-CRM. Sua implementação resultará, em última análise, em alcançar o nível mais alto de satisfação do cliente, o que é imperativo no setor bancário.

Palavras-chave: E-CRM; Lealdade do consumidor; Satisfação do empregado; Qualidade de serviço; Confiar em; Aceitação Tecnológica 


\section{Modelado de la efectividad de los sistemas electrónicos de gestión de la relación con el cliente (E-CRM): evidencia empírica de Pakistán}

\section{Resumen}

El propósito de este estudio es encontrar la relación entre la calidad del servicio, la lealtad, la confianza de los empleados y la aceptación de la tecnología con la efectividad de la gestión electrónica de las relaciones con los clientes. Las organizaciones están introduciendo tecnología basada en Internet para hacer que su negocio sea conveniente para los clientes existentes y potenciales y, a través de sus comentarios, también gestionan su rendimiento. La investigación se realizó en el sector bancario de Pakistán y se recopilaron datos de más de 500 empleados y clientes, incluidos los cinco principales bancos del país. Los hallazgos mostraron que solo la calidad del servicio y la lealtad fueron los predictores significativos de la efectividad del sistema E_CRM. Se anticipa que los resultados de este estudio no solo ampliarán el alcance del estudio para los investigadores a nivel académico, sino que también pueden hacer que los responsables políticos y los gerentes se den cuenta de la importancia del E-CRM. Su implementación finalmente resultará en lograr el mayor nivel de satisfacción del cliente que es imprescindible en el sector bancario.

Palabras clave: E-CRM; La lealtad del cliente; Satisfacción del empleado; Calidad de servicio; Confianza; Aceptación de tecnología

\section{Introduction}

Delicate usage of technology is the strategic resource for gaining competitive advantage for organizations irrespective of their nature and size of business. In today's world, every business desires to be successful through the utmost utilization of technology, while this also remains the fact that success or failure of any business depends upon the customer relationship management (Nasruddin \& Khalid, 2017). E-CRM is the tool that with the help of technology manages customer relations. E-CRM leads to satisfied customers resulting in efficiency in overall process of managing clients (Durai \& Stella, 2017).Nonetheless the major issue is the poor service quality provided by the service provider, which ultimately leads to dissatisfied customers. The emphasis of existing study is to investigate the rationale behind this poor quality of service and to improve the customers' relationship with firm by using effectiveness of electronic customer relationship management (E-CRM). According to Khodakarami and Chan (2014) firm's proficiency in congregating client's data and transform it into valuable information is possible only when firms have smooth working environment and their employees have relevant skills, so that they could help the firm to gain competitive advantage. Thus, firms 
may achieve effectiveness in overall process only when their clients are well treated because this treatment has the fore most influence on their perception about quality of service( $\mathrm{Yu}$, Nguyen, Han, Chen, \& Li, 2015).

E-CRM is the process of retaining valuable customers by incorporating different departments like sales, marketing and distribution to create a superior value for customers(Giannakis-Bompolis \& Boutsouki, 2014). It assists in improving the interaction between clients and organizational representatives through various sorts of forums like chat rooms that enable the organization to produce customized product or service rendering exactly to the dire needs of customers. It is through E-CRM that customers can easily give feedback and share their experience about the product or service that will help the firm to perform efficiently which will ultimately help to improve the overall process of the organization.

Electronic customer relationship management (E-CRM) has emerged in many sectors recently. It not only develops comprehensive changes in the setup of companies but also advances the medium of communication between company personnel and clients which will ultimately assisting developing the new models of business. Organizations are required to attract potential customers to buy their services or products, so that they may grow in their specific business (Ameri, Sadeh, \& Didehkhani, 2015). E-CRM is handful in adding up value to the entire process of buying and selling of an organization, as it satisfies the diverse needs and wants of customers more efficiently than its competitors and thus makes them happy and loyal with the organization. Ultimately, organizations not only upsurge their revenue but also their business starts flourishing through the implementation of newfangled tools of ECRM(Salehi, Kheyrmand, \& Faraghian, 2015).Considering the above, E-CRM becomes extremely important especially in banking sector(Singh \& Jain, 2017).Therefore, the purpose of this study is to find the relationship between service quality, loyalty and trust on the effectiveness of electronic customer relationship management in Pakistani banking industry.

\section{Literature Review}


In today's world, where organizations face the challenge of assorted competition and they are looking for better opportunities to gain competitive advantage, in this environment of competition customers are of primary focus for them(Javadi \& Azmoon, 2011; SIngh \&Jain, 2017). Electronic customer relationship management is characterized as any print or instrument through which organizations could perform effectively and gain profit while working online, interact with customers electronically and serve them competently (Mahdavi et al., 2008). According toSivaraks, Krairit, and Tang (2011) E-CRM is studied from customer perspective because customers are the main asset of any business, they are treated like special guests, hence for thit's imperative to improve the relationship between clients and banks personnel in Thai banking industry so the commitment, trust and loyalty can be improved in banking sector. Therefore if the customers are treated with care and their perceptions about the organization ought to be positive, then they would interact with firm again and again(Yu et al., 2015).

E-CRM is necessary not only for building long-term relationships with customers but also for maintaining existing customers as well as for attracting prospective customers(Aher \& Bhakkad, 2011). In a recent study, it is revealed that if the activities pertaining to advertisements are combined with the latest technology in an organization then these activities might make the customer relationship stronger with the organization and also the customers are more contented with the service they receive(Suri, 2016). E-CRM has emerged as the new conception in today's business because it involves dealing with customers over internet which is attractive and easy, moreover, it is time saving technique for building long-lasting relationships with customers(Choudhury \& Harrigan, 2014).

Five independent variables service quality, customers loyalty, trust, employee satisfaction and technology acceptance were used in this study. Electronic customer relationship management dependent variable being used in this study includes three dimensions, interpersonal communication, direct electronic mail and perceived rewards. 


\section{Service quality}

Service quality is getting considerable attention due to the reason that it has strong influence on customers' loyalty and moreover, it helps ingrowing the business(Santouridis \& Trivellas, 2010). Service quality is evaluated by the relevant purchaser or buyer, as every customer has a difference in perception of service received within a specific time span(Kassim \& Asiah Abdullah, 2010). Service quality has five dimensions reliability, tangible, assurance, empathy and responsiveness. Reliability refers to the aptitude to accomplish the relevant service within a given time frame as promised by the provider of that service. Tangible is defined as a facility which is physically present, it also includes the service personnel and the physical environment. Ananth, Ramesh, and Prabaharan (2011) in their study of private sector refer that tangibility means the equipment is of latest technology, environment and other facilities are eye catching and tempting to the customers. The dimension of service quality that promises to deliver service according to customers' perceptions is called assurance. According to Sadek et al. (2010), if the firm's personnel are friendly with the customers and treat them with generosity then assurance is gained straightforwardly. Empathy refers to the care or attention which is given to each customer and make them feel to be the part of that firm. Finally, the last dimension of service quality is responsiveness making sure too ffer the best services in no time and service personnel are available to help the customers at all time (Vasumathi \& Subashini, 2015).

\section{H1: Service quality is positively associated with the effectiveness of the E-CRM.}

\section{Customer's loyalty}

Customer's loyalty is becoming of prime importance and critical to gain the competitive advantages in banking sector. Besides this, due to advancements in the nature of services rendered to customers, it has become challenging for banking sector in Pakistan to maintain customers' loyalty. Loyalty is defined as the customer's intent to buy a product or service repeatedly with the same organization (Bobâlcă, 2013).Organizations turn out to be successful in today's market when its customers are loyal to it and henceforth it may achieve competitive advantage. Banks can easily gain customer loyalty by implementing E-CRM in their overall process(Abu-Shanab \& Anagreh, 2015). 
Customers loyalty has two dimensions behavioral loyalty, and attitudinal loyalty. Behavioral loyalty refers to a customer's conduct to repurchase a product or service due to their liking of a particular brand. Though this definition offers a relatively objective measurement of customer loyalty, yet this approach does not provide any proper explanation of the existence of loyalty. Attitudinal loyalty reflects the emotional or psychological state of the customer to repurchase any product or service and to recommend it to the other people. According to this approach, merely describing the actual behavior of the customer is not sufficient, rather than proper appraisal and portrayal of customers is also required to understand the pattern of their preferences(G. L. Chen, Yang, Chang, \& Lee, 2017).

\section{H2: Loyalty of customers is positively associated with the effectiveness of the E-CRM.}

\section{Trust}

Trust is a dominant factor in conducting any business and no deal is carried out without the element of trust in it(Wu \& Tsang, 2008). Online customers may get trust through various tools like looking detail sat the website or beholding at the information delivered by the service provider to its customers (Mou, Shin, \& Cohen, 2017). In internet banking trust is a vital factor as it leads to customer satisfaction and customer loyalty. Various researchers argue that by building online trust, service providers give the customers an image that they can secure their transactions by all means and also protect them against any inconvenience in the future (Poon et al., 2017; Schmidt, Ranney, Noar, \& Goldstein, 2017).The perception of clients that organization is offering themservice or product according to their needs and requirements would definitely help in retaining them with that organization(Oliveira, Alhinho, Rita, \& Dhillon, 2017; Poon et al., 2017).

There are two levels of trust in any organization namely: Credibility and Benevolence, this division of trust into two dimensions can bring better understanding about the connotation of trust in any business. Generally, trust has two dimensions credibility and benevolence. Credibility refers to the customers' level of trust on their provider of services or products that latter are fully equipped with latest techniques and acquaintance of providing high quality 
service. It is defined as the perception of clients that organization is offering service or product according to the needs and requirements of customers to make them loyal and ultimately to retain them with the specific organization (Flavián \& Guinalíu, 2006). Benevolence has a major impact on trust of customer and they become loyal with that firm.

\section{H3: $\quad$ Trust of customers is positively associated with the effectiveness of the E-CRM}

\section{Employee Satisfaction}

Employees are well thought-out to be the most significant component in flourishing any organization (Habibizad Navin, Jafari Navimipour, Rahmani, \& Hosseinzadeh, 2014). Employees' satisfaction is perceived as vital for the organizations as if employees are satisfied with the organization then they in due course turn customers into loyal ones as well. Accordingly, satisfaction is defined as the measure of fulfillment of employees in different types of circumstances (Islam, 2014). Yeh (2014) has further explained that employees' satisfaction is the set of emotions regarding different aspects of organization e.g. physical environment etc. with which employees are contended. Ahmad and Tarmudi (2012)have described that employees turn to be loyal with the organization only when organization appreciates them and gives them opportunities to grow in the form of trainings, fringe benefits or some sort of learning programs. Employees' satisfaction and loyalty are one of the biggest challenges that banking sector is confronting in contemporary competitive market. Various studies have been conducted to identify factors of workers' satisfaction but their research work only concentrated on developed countries (Hassan, Hassan et al. 2013).

Organizational culture is one of the driver of employee satisfaction and key determinant of employee's behavior or perception at workplace, if working environment is appropriate for the employees then they would continue enjoying at workplace. AsHowell and Annansingh (2013) have argued that culture of firm impacts on the personality of employees and polishes the behavior of employees with the passage of time. Organizational culture is defined as "concoction of attitudes, perceptions, beliefs and values of all relevant persons intricated in it and have an impact on the organization"(Habidin, Ali, Khaidir, Shazali, \& Jusoh, 2015). 
Organizational must be flexible in terms of rules and regulation but it does not mean organization restrict innovation.

\section{H4: Employee satisfaction is positively associated with the effectiveness of the E-CRM.}

\section{Technology Acceptance}

Technology acceptance is a very significant driver of E-CRM, as it helps the firm to innovate in many sectors and improve the process. According to Davis, Bagozzi, and Warshaw (1989) a framework for technology acceptance in organizations is technology acceptance model (TAM), through which we can measure the perceived ease of usage and apparent usefulness so the overall process will improve while using latest tools and techniques. Moreover, the success is dependent on the level of ease of use by the employees (Wahab \& Al-Momani, 2010).Elearning system is considered to be the effective technique of learning through internet(Lara, Lizcano, Martínez, Pazos, \& Riera, 2014). It is considered to be the most prominent method for educating employees at distant places so that they could achieve high returns(T.-L. Chen, 2014). The success of every organization is dependent on the infrastructure of that firm, because it is the most prominent reason for success or failure of any firm(Navimipour \& Soltani, 2016). Infrastructure capability is the main thing that delivers support for executing CRM in any firm(Chuang \& Lin, 2013).

CRM technology will improve the relationship among the two parties and inspire the customers by providing superior customers' products and services (Wang \& Feng, 2012). By utilizing electronic technology firms create chat forums (Trainor, 2012) through which customers might interact with other customers to share their experiences, thus enabling the organization to provide support for the clients and guide them in the right direction and also to solve the problem of diverse customers (Bagozzi \& Dholakia, 2006; Trainor, 2012). Hence ECRM is percieved as the protuberant tool that enables the people to best utilize the technology and be benefited from them (Chang, Park, \& Chaiy, 2010). 


\section{H5: Technology acceptance among employees is positively associated with the effectiveness of the E-CRM}

\section{Theoretical Framework}

The theoretical framework of the existing study is based on dependent variable effectiveness of electronic customer relationship management (E-CRM) and its relationship with independent variables: (1) Technology Acceptance, (2) Employee Satisfaction, (3) Service Quality, (4) Loyalty and (5) Trust. Each variable has its own dimensions and has an impact on these variables. Figure 1depicts the relationship between dependent variable electronic customer relationship management (E-CRM) with the independent variable technology acceptance, employee satisfaction, service quality, loyalty and trust. All the independent variables have further some dimensions. The conceptual model for the current study is given in Figure 1.

\section{Methodology}

The current study was designed on the cross-sectional research approach having a deductive research design, based on quantitative research techniques and a self-reported survey questionnaire. The current study uses "Cross-Sectional" approach for gathering the data. Data as collected from more than 500 respondents in the banking sector of Pakistan. It was gathered from thirty four branches of banks including, five branches of public sector banks, twenty one of private sector banks, three of specialized banks and five branches of foreign banks. Simple random sampling technique was used for the purpose of data collection, whereas, respondents were selected randomly. Adopted questionnaire was utilized in carrying out this research. It had two parts, one was about the demographic information of the respondent and other was about the latent variables, their dimensions and items.

\section{Instrumentation}


The scale of service quality was adopted from Zeithaml, Parasuraman et al. (1990) and Zeithaml, Berry et al. (1996) consisting of sixteen items. Technology acceptance consists of ten items and was measured using Davis, Bagozzi et al. (1989) and Ravichandran, Lertwongsatien et al. 2005 sclae. Trust consists of eight items and was adopted from Hess (1995) and Sirdeshmukh, Singh et al. (2002). Customer loyality was measured using scale of Zeithaml, Berry et al. (1996) and Fullerton (2005) and consists of six items. Employee satisfaction was measured using the scale of Calantone, Cavusgil et al. (2002) and Yang (2003) and consists of ten items. However, employee customer relationship management consists of nine items and scale was adopted from Lam, Cheung et al. (2013).

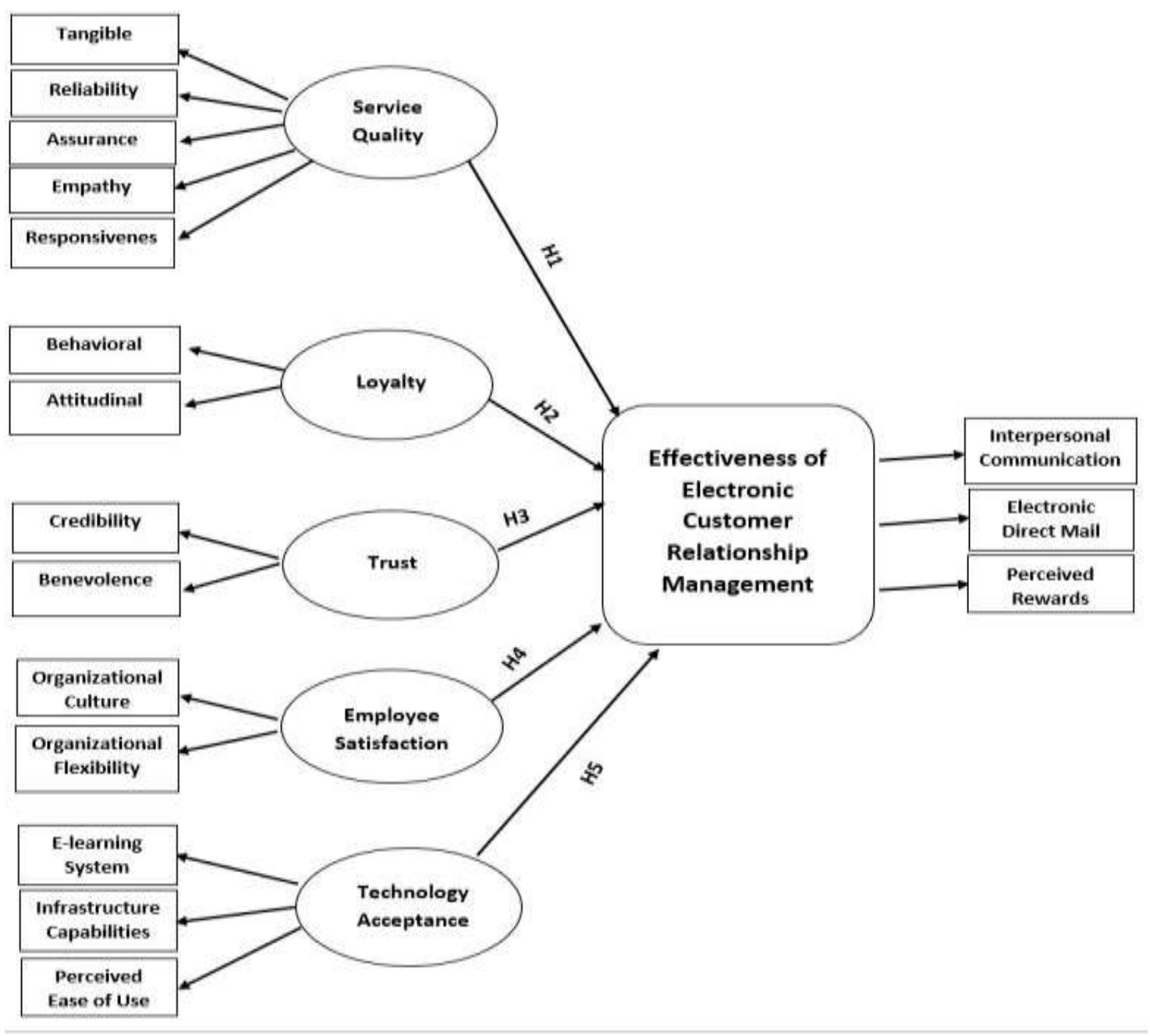

\section{Data Analysis}

Figure 1: Theoretical Framework 
The research model was developed in this study for the purpose of analysis. we followed the Partial Least Squares (PLS) analysis using Smart PLS 3.2.6 software (Ringle, Wende \& Becker, 2015). Measurement model was tested proceeded by an investigation of the structural model by following the guidelines given in the literature (Anderson \& Gerbing, 1988; Hair et al., 2017).Factor loading, reliability and validity of all dimensions was measured and then we proceeded towards structure equation modelling and all hypothesis were tested accordingly.

\section{Measurement Model}

The model was developed with 6 latent variables and their several dimensions (i.e. Service Quality with 5 dimensions, Loyalty with 2 dimensions, Trust with 2 dimensions, Satisfaction with 2 dimensions, Technology Adoption with 3 dimensions and E-CRM Effectiveness with 3 dimensions). Accordingly, first order factors were tested followed by the second order factor validity and reliability. As suggested by Hair et al. (2017) we used the factor loadings, average variance extracted (AVE) and composite reliability (CR) to test the convergent validity followed by the discriminant validity.

As shown in table 1 and table 2, all the first order factors showed ladings was more than 0.7, AVE > 0.5 and $\mathrm{CR}>0.7$ thus allowing us to conclude the measures are both valid and reliable. The second order factors also passed the 3 criteria's thus both the first order and second order factors are valid and reliable.

The discriminant validity was tested following the suggestion of Fornell and Larcker (1981) who suggested that discriminant validity is achieved if the square root of the AVE is greater than all the correlations in the same row and column of the particular construct. As shown in Table 2, discriminant validity of the constructs can be ascertained. Table 3 which shows the HTMT criterion (Henseler et al., 2015) also passed the 0.85 (Kline, 2011) threshold indicating discriminant validity was established. 


\section{Table 1}

Convergent Validity of First Order Factors

\begin{tabular}{|c|c|c|c|c|}
\hline Construct & Item & Loadings & CR & AVE \\
\hline \multirow[t]{4}{*}{ Reliability } & REL1 & 0.736 & 0.831 & 0.552 \\
\hline & REL2 & 0.796 & & \\
\hline & REL3 & 0.720 & & \\
\hline & REL4 & 0.721 & & \\
\hline \multirow[t]{3}{*}{ Tangibility } & TAN1 & 0.807 & 0.766 & 0.524 \\
\hline & TAN2 & 0.703 & & \\
\hline & TAN3 & 0.652 & & \\
\hline \multirow[t]{3}{*}{ Empathy } & EM1 & 0.768 & 0.810 & 0.568 \\
\hline & EM2 & 0.817 & & \\
\hline & EM3 & 0.712 & & \\
\hline \multirow[t]{3}{*}{ Assurance } & ASS1 & 0.768 & 0.760 & 0.515 \\
\hline & ASS2 & 0.641 & & \\
\hline & ASS3 & 0.778 & & \\
\hline \multirow[t]{3}{*}{ Responsive } & RES1 & 0.784 & 0.824 & 0.610 \\
\hline & RES2 & 0.773 & & \\
\hline & RES3 & 0.786 & & \\
\hline \multirow[t]{3}{*}{ Attitudinal Loyalty } & ATT1 & 0.843 & 0.863 & 0.680 \\
\hline & ATT2 & 0.894 & & \\
\hline & ATT3 & 0.727 & & \\
\hline \multirow[t]{3}{*}{ Behavioral Loyalty } & BEH1 & 0.775 & 0.768 & 0.526 \\
\hline & BEH2 & 0.670 & & \\
\hline & BEH3 & 0.727 & & \\
\hline \multirow[t]{3}{*}{ Benevolence } & BEN1 & 0.762 & 0.847 & 0.649 \\
\hline & BEN2 & 0.863 & & \\
\hline & BEN3 & 0.789 & & \\
\hline \multirow[t]{3}{*}{ Credibility } & CRE1 & 0.706 & 0.798 & 0.570 \\
\hline & CRE2 & 0.772 & & \\
\hline & CRE3 & 0.784 & & \\
\hline Inter-personal Communication & IPC1 & 0.797 & 0.814 & 0.513 \\
\hline
\end{tabular}




\begin{tabular}{|c|c|c|c|c|}
\hline & IPC2 & 0.790 & & \\
\hline & IPC3 & 0.721 & & \\
\hline \multirow[t]{3}{*}{ Electronic Direct Mail } & EDM1 & 0.817 & 0.788 & 0.555 \\
\hline & EDM2 & 0.736 & & \\
\hline & EDM3 & 0.675 & & \\
\hline \multirow[t]{3}{*}{ Perceived Rewards } & PR1 & 0.867 & 0.869 & 0.688 \\
\hline & PR2 & 0.833 & & \\
\hline & PR3 & 0.787 & & \\
\hline \multirow[t]{4}{*}{ Infrastructure Capabilities } & IC1 & 0.644 & 0.821 & 0.536 \\
\hline & IC2 & 0.770 & & \\
\hline & IC3 & 0.755 & & \\
\hline & IC4 & 0.753 & & \\
\hline \multirow[t]{3}{*}{ Perceived Ease of Use } & PEU1 & 0.775 & 0.779 & 0.540 \\
\hline & PEU2 & 0.713 & & \\
\hline & PEU3 & 0.715 & & \\
\hline \multirow[t]{3}{*}{ E-learning System } & ELS1 & 0.743 & 0.826 & 0.614 \\
\hline & ELS2 & 0.855 & & \\
\hline & ELS3 & 0.749 & & \\
\hline \multirow[t]{4}{*}{ Organizational Flexibility } & FLEX1 & 0.696 & 0.832 & 0.555 \\
\hline & FLEX2 & 0.851 & & \\
\hline & FLEX3 & 0.768 & & \\
\hline & FLEX4 & 0.650 & & \\
\hline \multirow[t]{5}{*}{ Organizational Culture } & $\mathrm{OC} 1$ & 0.700 & 0.846 & 0.524 \\
\hline & $\mathrm{OC} 2$ & 0.752 & & \\
\hline & OC3 & 0.736 & & \\
\hline & $\mathrm{OC} 4$ & 0.737 & & \\
\hline & OC5 & 0.692 & & \\
\hline
\end{tabular}


Table 2

Convergent Validity of Second Order Factors

\begin{tabular}{|c|c|c|c|c|}
\hline Construct & Item & Loadings & $\mathbf{C R}$ & AVE \\
\hline \multirow[t]{5}{*}{ Service Quality (SQ) } & Reliability & 0.833 & 0.878 & 0.592 \\
\hline & Tangibility & 0.704 & & \\
\hline & Empathy & 0.732 & & \\
\hline & Assurance & 0.772 & & \\
\hline & Responsive & 0.799 & & \\
\hline \multirow[t]{2}{*}{ Loyalty } & Attitudinal Loyalty & 0.912 & 0.868 & 0.768 \\
\hline & Behavioral Loyalty & 0.839 & & \\
\hline \multirow[t]{2}{*}{ Trust } & Benevolence & 0.891 & 0.865 & 0.762 \\
\hline & Credibility & 0.855 & & \\
\hline \multirow{3}{*}{$\begin{array}{l}\text { E-CRM Effectiveness } \\
\text { (E-CRM) }\end{array}$} & Inter-personal Communications & 0.863 & 0.879 & 0.708 \\
\hline & Electronic Direct Mail & 0.856 & & \\
\hline & Perceived Rewards & 0.804 & & \\
\hline \multirow{3}{*}{$\begin{array}{l}\text { Technology Adoption } \\
\text { (TA) }\end{array}$} & Infrastructure Capabilities & 0.726 & 0.823 & 0.609 \\
\hline & Perceived Ease of Use & 0.845 & & \\
\hline & E-learning System & 0.765 & & \\
\hline \multirow[t]{2}{*}{ Satisfaction (SAT) } & Organizational Flexibility & 0.809 & 0.831 & 0.711 \\
\hline & Organizational Culture & 0.876 & & \\
\hline
\end{tabular}

Table 3

Discriminant Validity (Fornell \& Larcker)

\begin{tabular}{llllll}
\hline Construct & E-CRM & Loyalty & SAT & SQ & TA \\
\hline E-CRM & $\mathbf{0 . 8 4 1}$ & & & & \\
Loyalty & 0.457 & $\mathbf{0 . 8 7 6}$ & & & \\
TA & -0.014 & 0.055 & 0.636 & -0.032 & $\mathbf{0 . 7 8 0}$ \\
\hline
\end{tabular}

Note: Values on the diagonal (bolded) are square root of the AVE while the off-diagonals are correlations 


\section{Table 4}

Discriminant Validity (HTMT)

\begin{tabular}{llllll}
\hline Construct & E-CRM & Loyalty & SAT & SQ & TA \\
\hline E-CRM & & & & \\
Loyalty & 0.567 & & & \\
SAT & 0.138 & 0.101 & & \\
SQ & 0.567 & 0.835 & 0.147 & & \\
TA & 0.141 & 0.140 & 0.818 & 0.144 \\
\hline
\end{tabular}

\section{Table 5}

Hypothesis Testing

\begin{tabular}{|c|c|c|c|c|c|c|c|c|c|}
\hline Hypothesis & Relationship & $\begin{array}{l}\text { Std } \\
\text { Beta }\end{array}$ & $\begin{array}{l}\text { Std } \\
\text { Error }\end{array}$ & t-value & $\begin{array}{l}\text { p- } \\
\text { value }\end{array}$ & LL & $\mathbf{U L}$ & $f^{2}$ & VIF \\
\hline H1 & $\mathrm{SQ} \rightarrow \mathrm{E}-\mathrm{CRM}$ & 0.293 & 0.087 & 3.369 & 0.001 & 0.103 & 0.454 & 0.052 & 2.237 \\
\hline H2 & $\begin{array}{l}\text { Loyalty } \rightarrow \text { E- } \\
\text { CRM }\end{array}$ & 0.216 & 0.095 & 2.284 & 0.023 & 0.052 & 0.401 & 0.025 & 2.506 \\
\hline H3 & $\begin{array}{l}\text { TRUST } \rightarrow \text { E- } \\
\text { CRM }\end{array}$ & 0.056 & 0.065 & 0.865 & 0.387 & 0.000 & 0.169 & 0.002 & 2.511 \\
\hline H4 & $\mathrm{SAT} \rightarrow \mathrm{E}-\mathrm{CRM}$ & 0.048 & 0.045 & 1.055 & 0.292 & 0.001 & 0.145 & 0.002 & 1.692 \\
\hline H5 & TA $\rightarrow$ E-CRM & -0.049 & 0.044 & 1.097 & 0.273 & -0.147 & -0.001 & 0.002 & 1.708 \\
\hline
\end{tabular}

\section{Structural Model}

To assess the structural model Hair et al. (2017) has suggested to look at the R square, beta and the corresponding t-values via a bootstrapping procedure with a resample of 5,000 (Mahmud et al., 2017). There was no problem of multicollinearity as all the VIF values were less than 5 (Hair et al., 2017). Then the effects of the independent variables on the dependent

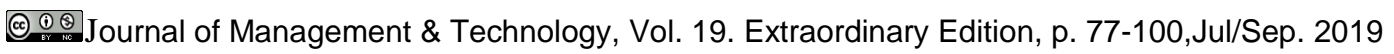


variable were observed as shown in Table 5 , the $\mathrm{R}$ square was 0.265 , indicating that the Service Quality $\left(\beta=0.293, \mathrm{p}<0.01, \mathrm{BC}_{0.95} \mathrm{LL}=0.103\right.$ and $\left.\mathrm{UL}=0.454\right)$ and Loyalty $(\beta=0.216, \mathrm{p}<$ $0.05, \mathrm{BC}_{0.95} \mathrm{LL}=0.052$ and $\left.\mathrm{UL}=0.401\right)$ together explained $26.5 \%$ variance in $\mathrm{E}-\mathrm{CRM}$ Effectiveness while Trust, Satisfaction and Technology Adoption were not significant. Thus H1, H2were supported while H3, H4 and H5 were not supported.

Finally we ran the blindfolding procedure with a distance of 7 to assess the predictive relevance of the model. The model possesses predictive relevance for specific endogenous constructs if the Q square value amounts to be greater than 0 (Fornell \& Cha, 1994; Hair et al. 2017). In this study, the $Q$ square value was 0.103 which was greater than 0 indicating that the predictive relevance was acceptable.

\section{Discussion}

E-CRM is an assortment of all applicable tools and internet based services that lead to quality service for attracting the new customers and retaining the old ones. According toTaherikia and Rezaei (2015) the impact of service quality is significant on the customers' satisfaction which ultimately leads to customers' loyalty in banking sector. The results of this study portray the positive relationship of service quality with E-CRM. If the firm personnel is friendly with the customers and treat them with generosity, then assurance is gained easily(Sadek et al., 2010).Implementation of E-CRM in the banking sector will help customers to have access to their information all time which will consequently help the customers to avail benefits from the internet(Abu-Shanab \& Anagreh, 2015).Whether the customer is buying online or availing the service from the front desk, trust is considered to be the primary factor for maintaining long-term relationship with the clients(Toufaily, Souiden, \& Ladhari, 2013).When the customers are dissatisfied then they complain and engage in negative word of mouth with the firm personnel, that leads to negative response and customers switch to other service providers(Kandampully, Zhang, \& Bilgihan, 2015).

First hypothesis is focused on the quality of service, by enhancing the quality of service organizations can achieve high level of customer satisfaction. Service quality might be 
enhanced through its dimensions, which may contribute to the high level of service quality resulting in high level of satisfied customers, who would build strong relationship between organization and customers. From this study, it is inferred that there is a positive or significant relationship between service quality and electronic customer relationship management. In support of four second hypothesis, we observed a direct and positive relationship between loyalty of customers and the electronic customer relationship management. The results specified that increase in electronic customer relationship management through multiple means will lead to increase in customer's loyalty.

Customers are considered to be the backbone of any organization. Therefore, trust is playing the main role in the effectiveness of electronic customer relationship management. In addition, this study verified the relationship between trust of customers and effectiveness of electronic customer relationship management. The relationship exhibits that the impact of customers trust on effectiveness of E-CRM is insignificant. Moreover, H4 and H5 were also not supported because employee satisfaction and technology acceptance is not positively related to Electronic customer relationship management. Employee satisfaction depends on various types of facilities provided by the firm moreover, technology is the basic factor to improve the services offered by the firm.

E-CRM in organizations will help and provide vast range of services according to the customer's demand and create opportunities to further grow their business and attract new customers. In this way, these organizations can have competitive advantage over other firms. Accordingly, organizations should be flexible enough to adopt any kind of changes that are profitable for the firm's operation(Navimipour \& Soltani, 2016).Now-a-days, e-learning technique is considered to be the most convenient method of learning for every organization (Navimipour \& Zareie, 2015).Electronic banking is one of the primary technology based service system in this direction. This service started in 90's and now has emerged as a main segment of banking sector around the globe(Kumar \& Sriram, 2016).

The main contribution in existing study is in conceptual model pertaining to the impact of various factors on electronic customer relationship management. The model included the impact of service quality, loyalty of customers and trust of customers on the effectiveness of E- 
CRM. The current study includes the impact of these variables in banking environment which is a service firm. Previous researches have neglected these points and asked the future researchers to make their contribution on these variables. The banks are the place where multiple risk taking activities are conducted. E-CRM ought to be used to enhance employees' performance and customers trust and loyalty level to build up good cross-functional interactions and also to achieve greater satisfaction level amongst customers and employees working in banks. Furthermore, the findings of this study might be useful for academicians as well as practitioners and managerial decision makers in banking sector.

So far no previous research is conducted to check the relationship of variables including service quality, loyalty of customers and trust of customers with E-CRM simultaneously. However, it is imperative for policy makers to have a keen view of the environment of the banks, so that they can make rules and policies accordingly. So, based on the above discussion, it may be concluded that E-CRM is playing an important role in developing a long-lasting relationship with existing customers and also in attracting potential customers, that proves to be productive for the organization in gaining higher profits.

\section{Conclusion}

The emergence of strong web based technology and internet facility will help to boost up the quality of business which ultimately satisfies the customers and end users. Customers now want to connect with the service providers electronically, so many firms are now changing their conventional business in to online stores to facilitate the customers. Customers are considered to be the backbone of any organization. E-CRM will help and provide vast range of services according to the customer's demand and create opportunities for further growth of the businesses. These organizations may gain competitive advantage over other firms. The first research question was about relationship between electronic customer relationship management (E-CRM) and Service Quality. Although result indicates positive and significant relationship between E-CRM and service quality. Which shows that if the quality of the provider is satisfactory then the customer gets attracted towards the service. Thus quality is very much dependent on the service provider which exhibits the positive relationship between the service 
provider and consumers. The second research question is validating the relationship or impact of loyalty over E-CRM. The results exhibited that loyalty of customer is significantly related with the electronic customer relationship management. The result indicated that increase in electronic customer relationship management through multiple means will lead to increase in customer's loyalty. Loyalty means that how much the customer is satisfied with your firm, the level of satisfaction is dependent on the services and quality of product. The third research question was about the relationship among customer trust and effectiveness of electronic customer relationship management. The results indicated that the trust of customers is not positively related with E-CRM. The relationship exhibits that the impact of customers trust on effectiveness of E-CRM is insignificant.

The forth research question specifics the relationship among employee satisfaction and E-CRM. Employee satisfaction is dependent on the way customers deal electronically with the firm The final conclusion inferred from the results is that employee's satisfaction is not positively related to electronic customer relationship management. The last research question was about the impact of technology acceptance on effectiveness of electronic customer relationship management. The results show that these two variables are negatively related with each other and have insignificant impact on each other. These findings are useable for managers and policy makers, who try to strengthen their businesses and attract new customers through providing different service over rival firms.

\section{Limitation and Future Direction}

There are some limitations in the study which can be improved in future research, these limitations are: firstly, the results cannot be generalized for all settings of organization because every organization has its own set-up of managing customers especially in the context of developing countries. The research is conducted in banking sector only therefore results may not be generalized for other sectors or for other businesses. Secondly, the type of this research design is cross-sectional, while future research should consider longitudinal design settings. 
Future researcher may encourage involving investigating the other dimensions of service quality like courtesy, competence security and communication. Furthermore, future research might investigate the impact of these variables in different settings like in manufacturing firms or in online businesses of selling products like amazon.com, x-mart, olx.com and from many other online firms which can sell their products completely online. Future research may also use customer loyalty and trust as mediators in the relationship between electronic customer relationship management and service quality.

\section{Refrences}

Abu-Shanab, E., \& Anagreh, L. (2015). Impact of electronic customer relationship management in banking sector. International Journal of Electronic Customer Relationship Management, 9(4), 254-270.

Anderson, J. C., \&Gerbing, D. W. (1988). Structural Equation Modeling in Practice: A Review and Recommended Two-Step Approach. Psychological Bulletin, 103(3), 411-423

Aher, A., \& Bhakkad, D. (2011). CRM in banking sector: impact and reality. National, Registered, Recognized and referred-Journal: Research Link, 10, 140-142.

Ahmad, M. A., \& Tarmudi, S. M. (2012). Generational differences in satisfaction with elearning among higher learning institution staff. Procedia-Social and Behavioral Sciences, 67, 304-311.

Ameri, M., Sadeh, E., \& Didehkhani, H. (2015). Review: Presenting Management Model of Relationship with Electronic Customer (e-CRM), Customer Satisfaction and Loyalty. Turkish Journal of Scientific Research. Vol, 2(2), 44-52.

Bobâlcă, C. (2013). STUDY OF CUSTOMERS'LOYALTY: DIMENSIONS AND FACETS. Management \& Marketing-Craiova(1), 104-114.

Chen, G. L., Yang, S. C., Chang, R. M., \& Lee, T. L. (2017). The Antecedents of Brand Loyalty Building in Fan Page of Facebook. Paper presented at the Proceedings of the 4th Multidisciplinary International Social Networks Conference on ZZZ.

Chen, T.-L. (2014). Exploring e-learning effectiveness perceptions of local government staff based on the diffusion of innovations model. Administration \& Society, 46(4), 450-466.

Choudhury, M. M., \& Harrigan, P. (2014). CRM to social CRM: the integration of new technologies into customer relationship management. Journal of Strategic Marketing, 22(2), 149-176.

Chuang, S.-H., \& Lin, H.-N. (2013). The roles of infrastructure capability and customer orientation in enhancing customer-information quality in CRM systems: Empirical evidence from Taiwan. International Journal of Information Management, 33(2), 271-281.

Davis, F. D., Bagozzi, R. P., \& Warshaw, P. R. (1989). User acceptance of computer technology: a comparison of two theoretical models. Management science, 35(8), 982-1003.

Durai, T., \& Stella, G. (2017). A Study On The Effect Of Electronic Customer Relationship Management (ecrm) On Customer Satisfaction Of E-Commerce Websites. Journal of Marketing Strategy, 5(3), 332-339. 
Flavián, C., \& Guinalíu, M. (2006). Consumer trust, perceived security and privacy policy: three basic elements of loyalty to a web site. Industrial Management \& Data Systems, 106(5), 601-620.

Giannakis-Bompolis, C., \& Boutsouki, C. (2014). Customer relationship management in the era of social web and social customer: an investigation of customer engagement in the Greek retail banking sector. Procedia-Social and Behavioral Sciences, 148, 67-78.

Habibizad Navin, A., Jafari Navimipour, N., Rahmani, A., \& Hosseinzadeh, M. (2014). Expert Grid: New Type of Grid to Manage the Human Resources and Study the Effectiveness of Its Task Scheduler. Arabian Journal for Science \& Engineering (Springer Science \& Business Media BV), 39(8).

Habidin, N. F., Ali, N., Khaidir, N. A., Shazali, N. A., \& Jusoh, O. (2015). Relationship between customer relationship management, service qualityimprovement and organizational performance in malaysian healthcare industry. International Journal of Innovation and Scientific Research, 14(2), 291-302.

Howell, K. E., \& Annansingh, F. (2013). Knowledge generation and sharing in UK universities: A tale of two cultures? International Journal of Information Management, 33(1), 32-39.

Islam, A. N. (2014). Sources of satisfaction and dissatisfaction with a learning management system in post-adoption stage: A critical incident technique approach. Computers in Human Behavior, 30, 249-261.

Javadi, M. H. M., \& Azmoon, Z. (2011). Ranking branches of System Group company in Terms of acceptance preparation of electronic Customer Relationship Management using AHP method. Procedia Computer Science, 3, 1243-1248.

Kandampully, J., Zhang, T., \& Bilgihan, A. (2015). Customer loyalty: a review and future directions with a special focus on the hospitality industry. International Journal of Contemporary Hospitality Management, 27(3), 379-414.

Kassim, N., \& Asiah Abdullah, N. (2010). The effect of perceived service quality dimensions on customer satisfaction, trust, and loyalty in e-commerce settings: A cross cultural analysis. Asia Pacific Journal of Marketing and Logistics, 22(3), 351-371.

Khodakarami, F., \& Chan, Y. E. (2014). Exploring the role of customer relationship management (CRM) systems in customer knowledge creation. Information \& Management, 51(1), 27-42.

Kumar, P., \& Sriram, B. (2016). Customer Satisfaction on E-banking Services Quality-An Analytical Study on Banks in Oman. Asian Journal of Research in Banking and Finance, 6(10), 10-29.

Lara, J. A., Lizcano, D., Martínez, M. A., Pazos, J., \& Riera, T. (2014). A system for knowledge discovery in e-learning environments within the European Higher Education AreaApplication to student data from Open University of Madrid, UDIMA. Computers \& Education, 72, 23-36.

Mou, J., Shin, D.-H., \& Cohen, J. F. (2017). Trust and risk in consumer acceptance of eservices. Electronic Commerce Research, 17(2), 255-288.

Moussavou, G., \& Mbohwa, C. (2013). Analysis organizational socialization impacts on employee performance and productivity at a South African financial company.

Nasruddin, N. H. M., \& Khalid, F. A. (2017). The Influence of Internal and External Forces in Adoption of Electronic Customer Relationship Management (ECRM) in Malaysian SMEs. The Social Sciences, 12(12), 2230-2235.

Navimipour, N. J., \& Soltani, Z. (2016). The impact of cost, technology acceptance and employees' satisfaction on the effectiveness of the electronic customer relationship management systems. Computers in Human Behavior, 55, 1052-1066. 
Navimipour, N. J., \& Zareie, B. (2015). A model for assessing the impact of e-learning systems on employees' satisfaction. Computers in Human Behavior, 53, 475-485.

Oliveira, T., Alhinho, M., Rita, P., \& Dhillon, G. (2017). Modelling and testing consumer trust dimensions in e-commerce. Computers in Human Behavior, 71, 153-164.

Poon, P., Poon, P., Albaum, G., Albaum, G., Yin, C.-Y., \& Yin, C.-Y. (2017). Exploring risks, advantages and interpersonal trust in buyer-salesperson relationships in direct selling in a non-western country. International Journal of Retail \& Distribution Management, 45(3), 328-342.

Sadek, D. M., Zainal, N. S., Taher, M. S. I. M., Yahya, A. F., Shaharudin, M. R., Noordin, N., ... Jusoff, K. (2010). Service quality perceptions between cooperative and Islamic banks of Britain. American Journal of Economics and Business Administration, 2(1), 1.

Salehi, S., Kheyrmand, M., \& Faraghian, H. (2015). Evaluation of the effects of e-CRM on customer loyalty (case study: Esfahan Branch's of Sepah Bank). Paper presented at the eCommerce in Developing Countries: With focus on e-Business (ECDC), 2015 9th International Conference on.

Santouridis, I., \& Trivellas, P. (2010). Investigating the impact of service quality and customer satisfaction on customer loyalty in mobile telephony in Greece. The TQM Journal, 22(3), 330-343.

Schmidt, A. M., Ranney, L. M., Noar, S. M., \& Goldstein, A. O. (2017). Development of the FDA Tobacco Credibility Scale (FDA-TCS). Tobacco Regulatory Science, 3(1), 47-55.

Singh, R. P., \& Jain, V. (2017). A Study of the Impact of Electronic Customer Relationship Management on Customer Loyalty by Using Structural Equation Modeling in Banking Sector. Researchers World, 8(2), 52.

Sivaraks, P., Krairit, D., \& Tang, J. C. (2011). Effects of e-CRM on customer-bank relationship quality and outcomes: The case of Thailand. The Journal of High Technology Management Research, 22(2), 141-157.

Suri, S. (2016). CRM Practices of SBI Bahrain \& The Customer's Perception Towards These Practices.

Taherikia, F., \& Rezaei, F. (2015). Investigating success factors influencing in e-CRM adoption: Evidence from banking industry. Management Science Letters, 5(1), 79-84.

Toufaily, E., Souiden, N., \& Ladhari, R. (2013). Consumer trust toward retail websites: Comparison between pure click and click-and-brick retailers. Journal of Retailing and Consumer Services, 20(6), 538-548.

Wahab, S., \& Al-Momani, K. (2010). The relationship between e-service quality and ease of use on customer relationship management (CRM) performance: an empirical investigation in Jordan mobile phone services. Journal of Internet Banking and Commerce, 15(1), 1.

Wu, J.-J., \& Tsang, A. S. (2008). Factors affecting members' trust belief and behaviour intention in virtual communities. Behaviour \& Information Technology, 27(2), 115-125.

Yeh, Y.-P. (2014). Exploring the impacts of employee advocacy on job satisfaction and organizational commitment: Case of Taiwanese airlines. Journal of Air Transport Management, 36, 94-100.

Yu, X., Nguyen, B., Han, S. H., Chen, C.-H. S., \& Li, F. (2015). Electronic CRM and perceptions of unfairness. Information Technology and Management, 16(4), 351-362.

Fornell, C., \& Cha, J. (1994). Partial least squares. In R.P. Bagozzi (Ed.). Advanced Methods in Marketing Research (pp. 52-78). Cambridge: Blackwell.

Fornell, C., \&Larcker, D. F. (1981). Evaluating structural equation models with unobservable variables and measurement error. Journal of Marketing Research, 18(1), 39-50. 
Hair, J. F., Hult, G. T. M., Ringle, C. M., \&Sarstedt, M. (2017). A primer on partial least squares structural equation modeling (PLS-SEM). 2nd ed., Sage: Thousand Oaks, CA.

Henseler, J., Ringle, C., \&Sarstedt, M. (2015). A New Criterion for Assessing Discriminant Validity in Variance-based Structural Equation Modeling. Journal of the Academy of Marketing Science, 43(1), 115-135.

Kline, R. B. (2011). Principles and practice of structural equation modeling. New York: Guilford Press.

Mahmud, I., Ramayah, T.,\&Kurnia, S. (2017). To Use Or Not To Use: Modelling End User Grumbling As User Resistance In Pre-Implementation Stage Of Enterprise Resource Planning System. Information Systems, 69, 164-179.

Ringle, C. M., Wende, S., \& Becker, J.-M. (2015). "SmartPLS 3." Boenningstedt: SmartPLS $\mathrm{GmbH}, \underline{\mathrm{http}: / / \mathrm{www} . \mathrm{smartpls.com}}$ 